\title{
Participation in proficiency programs and promotion of quality in transfusion services of Minas Gerais
}

\author{
Ângela Melgaço Ferreira ${ }^{1}$ \\ Stela Brener ${ }^{2}$ \\ Ricardo Vilas Freire de Carvalho ${ }^{3}$ \\ Marcele Cunha Ribeiro do Valle ${ }^{2}$ \\ Helio Moraes-Souza ${ }^{4,5}$ \\ 'Quality Control Department, Fundação \\ Centro de Hematologia e Hemoterapia do \\ Estado de Minas Gerais - Hemominas, \\ Belo Horizonte, MG, Brazil \\ ${ }^{2}$ Research Department, Fundação Centro \\ de Hematologia e Hemoterapia do \\ Estado de Minas Gerais - Hemominas, \\ Belo Horizonte, MG, Brazil \\ ${ }^{3}$ Technical Department, Fundação Centro \\ de Hematologia e Hemoterapia do \\ Estado de Minas Gerais - Hemominas, \\ Belo Horizonte, MG, Brazil \\ ${ }^{4}$ Department of Internal Medicine, \\ Universidade Federal do Triângulo \\ Mineiro - UFTM, Uberaba, MG, Brazil \\ ${ }^{5}$ Fundação Centro de Hematologia e \\ Hemoterapia do Estado de Minas Gerais \\ - Hemominas, Belo Horizonte, MG, Brazil
}

Conflict-of-interest disclosure:

The authors declare no competing financial interest

Submitted: 9/30/2011

Accepted: 12/2/2011

Corresponding author:

Helio Moraes-Souza

Universidade Federal do Triângulo

Mineiro - UFTM

Av. Getúlio Guaritá, 250 - Bairro Abadia

38025-440 - Uberaba, MG, Brazil

Phone: 5534 3312-5077

helio.moraes@dcm.uftm.edu.br

www.rbhh.org or www.scielo.br/rbhh

DOI: 10.5581/1516-8484.20120009
Objective: This study aimed at identifying associations between the participation of transfusion services in immunohematology external quality control programs and their accuracy in immunohematology testing and adaptation to technical and legal operational procedures.

Methods: From 2007 to 2009, a cross-sectional study was conducted in 219 transfusion services of the State of Minas Gerais who participated in this investigation by responding to a questionnaire and conducting a proficiency test comprising: $A B O$ and RhD phenotyping, irregular RBC antibody screening and cross-matching. Frequencies and bivariate analysis followed by binary logistic regression were used for statistical analysis.

Results: Transfusion services who participated in external quality control programs (32.4\%) and those that did not (67.6\%) obtained worrying error percentages in proficiency tests which may significantly increase blood transfusion risks. Shortfalls related to the establishment of protocols, standards and internal quality control were also significant. On comparing the two groups, transfusion services that participated in these programs had a 2.35 times higher chance of correct results in the proficiency panel testing, a 3.16 higher chance of having transfusional records and a 2.81 higher chance of performing preventive maintenance of equipment.

Conclusion: The study showed that independent factors associated to participation in external quality control programs suggest that more investment in internal quality control procedures is necessary and that more attention should be paid to current legislation.

Keywords: Quality control; Blood banks; Blood transfusion; Quality assurance, health care; Program evaluation

\section{Introduction}

Equitable, safe and rational access to blood imposes major challenges throughout the world. Many strategies with proven efficacy are adopted to overcome these challenges; these include Government support and the implementation of effective national policies, legislation and regulations with the efficient management of blood services.$^{(1)}$ However, several countries have shown slow progress in establishing these requirements.

According to the World Health Organization (WHO) and hemotherapy referral institutions, risks associated with blood transfusion can be significantly reduced by the introduction of quality control systems that include internal and external evaluations..$^{(1-4)}$

In Brazil, the government regulation of the Ministry of Health ${ }^{(5)}$ states that transfusion services (TSs) must participate in proficiency programs to ensure that standards and procedures are appropriately followed and that equipment, materials and reagents function correctly.

External Quality control programs (EQCP), coordinated by referral services, regularly provide test samples (proficiency panels) to laboratories and subsequently analyze the results. The aim of this is to provide participants methods to evaluation and improve their work, to periodically reappraise processes, to identify problems and to provide corrective and preventive measures. In addition to monitoring individual performance, EQCP identify trends, recognize the origin of errors and expand communication channels thus are an important source of information. ${ }^{(6-8)}$

In view of the above, the aim of this study was to identify any association between the participation of individual TSs of the State Blood Transfusion Service Network of Minas Gerais in EQCP and their performance in immunohematological tests using proficiency panels created for the study and adherence to legal technical and operational procedures. 


\section{Methods}

A cross-sectional study, part of "Transfusion safety: evaluation of the physical infrastructure and operational services of public blood banks in the State of Minas Gerais, 2007-2008" was developed in the Fundação Hemominas (Hemominas) in the period from January 2007 to April 2009.

The methodology of this prospective study was described in a parallel study on the operational and physical infrastructure of Hemorrede of the State of Minas Gerais. ${ }^{(9)}$

For analysis, the TSs were allocated to two groups: those that participated in EQCP and those that did not. Absolute frequencies and bivariate analysis followed by binary logistic analysis were used to compare the two groups. The choice of variables included in the model was based on technical relevance, estimates of the odds ratios (OD) and the $95 \%$ confidence interval, as well as the statistical value of the Fisher exact and Pearson's Chi-square tests $\left(\chi^{2}\right)$ with significance set for a $p$-value $<0.20$. The dependent variable was categorized by participation in EQCP with participation in these programs being the reference category. The variables were introduced in block with manual exclusion. The criterion for permanence of variables in the model was a significance level for $p$-value $<0.05$. $^{(10)}$ The EpiData (version 3.1) computer program was used for data entry and SPSS (version 17.0) and Epinfo (version 6.4) for statistical analyses.

\section{Results}

Of the 219 TSs that performed the proficiency test, 71 (32.4\%) had participated in EQCP.

On comparing the groups in relation to the results of the tests of the proficiency panels, it was found that the TSs that had participated in EQCP had a higher percentage of correct results. There were significant statistical differences between the two groups in respect to the classification of $\mathrm{RhD}$ and irregular red blood cell (RBC) antibody screening ( $\mathrm{p}$-value $=0.001$ and $\mathrm{p}$-value $<0.001$, respectively - Table 1).

A statistically significant difference ( $p$-value $<0.001$ ) was observed between the TSs that participated in the EQCP and those that did not in respect to false negative results for irregular RBC antibody screening. The difference was not statistically significant for false positive results $(\mathrm{p}$-value $=0.085 ;$ Figure 1$)$.

\begin{tabular}{|c|c|c|c|c|c|}
\hline \multirow[t]{2}{*}{$\begin{array}{l}\text { Pre-transfusion } \\
\text { tests }\end{array}$} & \multicolumn{2}{|c|}{$\begin{array}{l}\text { Participated in external } \\
\text { quality control programs } \\
\text { n (\%) }\end{array}$} & \multicolumn{2}{|c|}{$\begin{array}{l}\text { Did not participate in external } \\
\text { quality control programs } \\
\text { n (\%) }\end{array}$} & \multirow[t]{2}{*}{ p-value } \\
\hline & Correct & Incorrect & Correct & Incorrect & \\
\hline $\mathrm{ABO}$ classification * & $276(97.2)$ & $8(2.8)$ & $560(94.6)$ & $32(5.4)$ & 0.085 \\
\hline RhD classification * & $281(98.9)$ & $3(1.1)$ & $558(94.2)$ & $34(5.7)$ & 0.001 \\
\hline Antibody screening $* *$ & $120(84.5)$ & $22(15.5)$ & $201(68.0)$ & $95(32.0)$ & $<0.001$ \\
\hline Compatibility testing*** & $131(92.2)$ & $11(7.7)$ & $259(85.7)$ & $37(14.2)$ & 0.136 \\
\hline
\end{tabular}

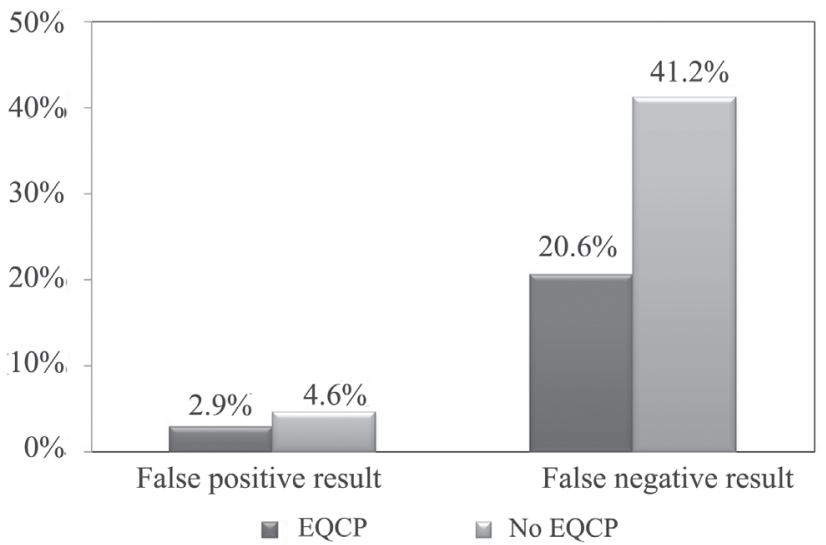

Figure 1 - Percentage of false positive and false negative results in irregular red blood cell antibody screening performed by State Transfusion Services that participated in external quality control programs and those that did not

EQCP: Participated in external quality control programs; No EQCP: Did not participate in external quality control programs 
Table 2 - Analysis of the parameters of compliance in accordance with current legislation of the 219 State Transfusion Services that had participated in External Quality control programs and those that had not - Minas Gerais, 2007-2008

\begin{tabular}{|c|c|c|c|c|c|}
\hline \multirow{3}{*}{ Parameter } & \multirow{2}{*}{\multicolumn{2}{|c|}{$\begin{array}{c}\text { Participated in external } \\
\text { quality } \\
\text { control programs } \\
\text { n }=71\end{array}$}} & \multirow{2}{*}{\multicolumn{2}{|c|}{$\begin{array}{c}\text { Did not participate in } \\
\text { external quality control } \\
\text { programs } \\
\mathrm{n}=148\end{array}$}} & \multirow{3}{*}{ p-value } \\
\hline & & & & & \\
\hline & $\mathrm{n}$ & $\%$ & $\mathrm{n}$ & $\%$ & \\
\hline \multicolumn{6}{|l|}{ Materials } \\
\hline Reagents with instructions for use & 52 & 73.2 & 89 & 60.1 & 0.058 \\
\hline Non-manual preparation of ' $\mathrm{O}$ ' $\mathrm{RBC}$ reagents (for irregular $\mathrm{RBC}$ antibody screening) & 55 & 77.5 & 84 & 56.8 & 0.016 \\
\hline Sera stored between $2^{\circ} \mathrm{C}$ and $8^{\circ} \mathrm{C}$ & 64 & 90.1 & 120 & 81.1 & 0.126 \\
\hline Use of RhD serum and Rh control from same manufacturer & 68 & 95.8 & 126 & 85.1 & 0.020 \\
\hline RBC suspensions in pre-transfusion tests & 63 & 88.7 & 124 & 83.8 & 0.332 \\
\hline \multicolumn{6}{|l|}{ Equipment } \\
\hline Specific refrigerator to store blood bags & 70 & 98.6 & 146 & 98.6 & 1.000 \\
\hline Specific refrigerator with adequate temperature & 62 & 87.3 & 124 & 83.8 & 0.469 \\
\hline Corrective maintenance of equipment & 58 & 81.7 & 108 & 73.0 & 0.159 \\
\hline Preventive maintenance of equipment & 40 & 56.3 & 35 & 23.6 & 0.000 \\
\hline \multicolumn{6}{|l|}{ Tests and Methods } \\
\hline Transfusion records & 29 & 40.8 & 18 & 12.2 & 0.000 \\
\hline $\mathrm{ABO} / \mathrm{RhD}$ phenotyping of each new recipient sample & 63 & 88.7 & 105 & 70.9 & 0.004 \\
\hline Research/Classification of irregular antibodies of recipients of packed red blood cells & 71 & 100.0 & 139 & 93.9 & 0.033 \\
\hline \multicolumn{6}{|l|}{ Transportation } \\
\hline Protocols of transportation for non-conforming procedures & 21 & 29.6 & 21 & 14.2 & 0.007 \\
\hline Registration of arrival and departure of blood & 67 & 94.4 & 129 & 87.2 & 0.129 \\
\hline SOPs/ Transportation of blood products & 21 & 29.6 & 20 & 13.5 & 0.004 \\
\hline Transport of blood products with thermometer and ice & 42 & 60.9 & 103 & 69.6 & 0.204 \\
\hline \multicolumn{6}{|l|}{ Working practice } \\
\hline Up-to-date SOPs / pre-transfusion tests & 23 & 32.4 & 24 & 16.2 & 0.006 \\
\hline \multicolumn{6}{|l|}{ Quality control } \\
\hline Quality control of reagents & 7 & 9.9 & 5 & 3.4 & 0.060 \\
\hline Sensitized RBCs/validation of antiglobulin tests & 16 & 22.5 & 11 & 7.4 & 0.002 \\
\hline \multicolumn{6}{|l|}{ Human resources } \\
\hline Clinical pathology technician & 40 & 56.3 & 52 & 35.1 & 0.003 \\
\hline
\end{tabular}

PRC: Packed red cells; SOP: Standard operating procedure; RBC: Red blood cells

Table 3 - Parameters in the final logistic regression model analyzing State Transfusion Services that had participated in external quality control programs and those that had not

\begin{tabular}{lccc}
\hline \multicolumn{1}{c}{ Parameter } & p-value & OR & $95 \%$ CI \\
\hline $\begin{array}{l}\text { Correct results of proficiency } \\
\text { panel testing }\end{array}$ & 0.008 & 2.35 & $(1.25-4.42)$ \\
$\begin{array}{l}\text { Transfusion records } \\
\text { Preventive maintenance of }\end{array}$ & 0.002 & 3.16 & $(1.50-6.63)$ \\
equipment & 0.002 & 2.81 & $(1.46-5.41)$ \\
\hline
\end{tabular}

95\% CI - 95\% confidence interval; OR - Odds ratio

Hosmer \& Lemeshow - p-value $=0.914$

Parameters included in the regression model with possible influence on test results are listed in Tables 2 and 3 .

On comparing the two groups, TSs that participated in EQCP presented a 2.35 times higher chance of having correct results for the proficiency panel testing, a 3.16 times higher chance of having transfusion records and 2.81 times higher chance of performing preventive maintenance of equipment.

\section{Discussion}

The current study found that about two-thirds of services did not participate in EQCP; this proportion deserves attention as it demonstrates non-compliance with mandatory and effective standards for the maintenance, improvement and control of procedures carried out by hemotherapy services. ${ }^{(4,5,8,11)}$ This assertion is confirmed by the results, since among the parameters of greater technical relevance major inadequacies were observed for STs that did not participate in the EQCP. Although factors related to existing legislation and technical standards are associated with the performance of TSs in EQCP, in practice, weak points were identified common to both study groups 
demonstrating that the EQCP should be reassessed in order to fully achieve goals. ${ }^{(4,8)}$ However, such weaknesses could also be attributed to failures in the qualification of staff, through training and/or periodic recycling as noted in a parallel study conducted with the same TSs (Brener, personal communication). Both groups showed inaccuracies in other mandatory tests carried out, which can significantly exacerbate the risks. A better performance was seen in $\mathrm{RhD}$ phenotyping and irregular RBC antibody screening of TSs that participated in EQCP; the number of false negative results in antibody screening was about two times higher in those who did not participate in programs, reinforcing the importance of universal EQCP.

The average correct $\mathrm{ABO}$ and $\mathrm{RhD}$ phenotyping and the irregular antibody RBC screening of participants in a Federal Government program (AEQ-IH/ANVISA/MS) held in the same period and using four proficiency panels were similar to the results of the current study for the TSs that had participated in EQCP. The same cannot be said for the other TSs of this study that did not participate in EQCP as they presented with major failings in the irregular RBC antibody screening results compared to other services around Brazil. ${ }^{(12)}$

Generally the shortcomings related to the establishment of protocols, norms and internal quality control were common and significant in both groups. The adequacy of these parameters may be primarily related to greater managerial commitment regardless of the complexity of services.

The correct results of the proficiency panels, existence of transfusion records and preventive maintenance of equipment remained in the final logistic regression model and were independently associated to participation in EQCP suggesting improvement in internal quality control procedures and more attention paid to the laws in force. ${ }^{(5)}$

Efficient EQCP together with periodic assessments of the performance of services enables their respective managements to verify the quality of immunohematological activities and, when necessary, investigate problems. ${ }^{(8,11)}$

An important aspect covered by the Gerência Geral de Sangue Outros Tecidos e Órgãos/Agência Nacional de Vigilância Sanitária is that, through the results of tests and attitudes of TSs in respect to proficiency programs, the health department can carry out more efficient inspections and act effectively to control TSs. ${ }^{(12)}$ Implementation of quality control systems and the adaptation of services depend on the establishment of monitoring strategies and systematic evaluations, as well as technical, institutional and regulatory progress. Accordingly, commitment of the authorities is needed to strengthen the national policy for a safe TS and of all professionals involved to acquire enough blood to cover the demand and comply with therapeutic goals.

\section{References}

1. World Health Organization. WHO Global consultation on universal access to safe blood transfusion, 9-11 June 2007, Ottawa, Canada [Internet]. Geneva: WHO; 2007. [cited 2009 Jun 21]. Available from: http://www.who.int/bloodsafety/ publications/ReportUniversalAccesstoSafeBloodTransfusion.pdf

2. Novaretti MC, Bonifácio SL, Medeiros VR, Ruiz AS, DorlhiacLlacer PE, Chamone DA. Dez anos de experiência em controle de qualidade em imunohematologia. Rev Bras Hematol Hemoter. 2009;31(3):160-5.

3. Novaretti MC, Bueno VJ, Dorlhiac-Llacer PE, Chamone DA. Controle de qualidade interno de reagentes em imunohematologia - Aspectos práticos. Rev Bras Hematol Hemoter. 2002;24(4):270-85.

4. Franco E. [Quality control of immunologic testing of blood in the region of the Americas]. Rev Panam Salud Publica 2003;13(23):176-82. Spanish

5. Brasil. Ministério da Saúde. Portaria MS no 1.353, de 13.06.2011 - DOU 1 de 14.06.2011. Aprova o regulamento técnico de procedimentos hemoterápicos [Internet]. Brasília, DF: MS; 2011. [cited 2011 Nov 20]. Available from: http://pegasus.fmrp.usp.br/ projeto/legislacao/port_min_1353.pdf

6. World Health Organization. External quality assessment of transfusion laboratory practice: guidelines on establishing an EQA scheme in blood group serology [Internet]. Geneva: WHO; 2004. [cited 2010 Jan 12]. Available from: http://www.who.int/ bloodsafety/EQA_in_Blood_Group_Serology.pdf

7. Associação Brasileira de Normas Técnicas. ABNT ISO/IEC/Guia 43:1:1999. Ensaios de proficiência por comparações interlaboratoriais. Parte 1: Desenvolvimento e operação de programas de ensaios de proficiência. Rio de Janeiro: ABNT; 1999. 17 p.

8. Melo L, Pellegrino Jr J, Bianco C, Castilho L. Twelve years of the Brazilian External Quality Assessment Program in immunohematology: benefits of the program. J Clin Lab Anal. 2005;19 (5):209-18.

9. Brener S, Carvalho RV, Ferreira AM, Silva MM, Valle MC, MoraesSouza H. Physical and operational infrastructure of transfusion services of the public blood bank network in the State of Minas Gerais, Brazil, 2007/2008. Rev Bras Hematol Hemoter. 2010; 32(6):455-62.

10. Hosmer DW, Lemeshow S. Applied logistic regression. 2nd ed. New York: John Wiley \& Sons; 2000.

11. Duran JA, Condeço J, Maia S, Rodrigues F, Amil M, Oliveira MG. Programa de Controlo de Qualidade Externo em Imuno-hematologia -4 anos de experiência das Regiões Norte e Centro - Rev ABO. 2001;5:21-3.

12. Agência Nacional de Vigilância Sanitária. Boletim do Programa de Avaliação Externa da Qualidade em Serviços de Hemoterapia [Internet]. Brasília: ANVISA; 2001-2008 [cited 2010 Mar 6]. Available from: http://portal.anvisa.gov.br/wps/wcm/connect/ Anvisa+Portal/Anvisa/Inicio/Sangue+Tecidos+e+Orgaos/ Assunto+de+Interesse/Avaliacao+Externa+da+Qualidade+-+AEQ/ 